British \& Irish Botany 2(4): 377-406, 2020

\title{
Galeopsis speciosa (Lamiaceae): an Open Vegetation seed bank community at Worsley in Salford (v.c.59), revealed during construction of the new Royal Horticultural Society Garden at Bridgewater
}

\author{
Michael J. Crawley \\ Imperial College London, Silwood Park, Ascot, SL5 7PY
}

Corresponding author: m.crawley@imperial.ac.uk

This pdf constitutes the Version of Record published on $7^{\text {th }}$ December 2020

\begin{abstract}
This paper provides a baseline flora for the site of the new garden of the Royal Horticultural Society at Worsley New Hall in Salford (v.c.59). During construction, $35,000 \mathrm{~m}^{3}$ of top-soil, sub-soil and spoil were stripped and stored onsite; species recruiting from these seed banks were monitored 2017-2020, leading to the description of a new Galeopsis speciosa Open Vegetation plant community. Four commercial wildflower mixes were used during post-construction landscaping in 2019, and their establishment was assessed in 2020. It will be interesting to follow the survival of these introduced species, many of which are not native to the site.
\end{abstract}

Keywords: landscaping; seed bank; RHS; introduced species; establishment; wildflower seed mix

\section{Introduction}

Francis Egerton (1736-1803), 3rd Duke of Bridgewater, made a fortune in the mid$18^{\text {th }}$ century from coal mines at Worsley in Lancashire. Known as a pioneer of canal construction, he is regarded as the father of British inland navigation. He commissioned the Bridgewater Canal to service the coal mines, the first true canal in the modern world, which was built for him by his agent John Gilbert with advice from the engineer James Brindley. It opened in 1761. Subsequently, the Liverpool to Manchester canal was completed by the same team, and these ventures led to Egerton becoming the richest nobleman in England by the end of the $18^{\text {th }}$ century. Worsley Old Hall was built in the late 16th century as the manor house for the Worsley estate, $13 \mathrm{~km}$ west of Manchester. The Duke inherited the estate in 1748, and commissioned the construction of the so-called Brick Hall, a classical-style building, which was completed in the 1760s. The Duke did not marry, and the dukedom expired with him. The Brick Hall was demolished between December 1844 and August 1845 (Leigh Road now runs over the site of the former building). The Duke's will placed the canals and estates in a trust which did not expire until 19 October 1903, when the whole property passed to the undivided control of Francis Egerton, 3rd Earl of Ellesmere. The canals had by then been transferred to the Bridgewater Navigation Company in 1872, by whom they were sold in 1887 to the Manchester Ship Canal Company. 
Francis Egerton (1800-1857), 1st Earl of Ellesmere was heir to this fortune. He built Worsley New Hall to a design by Edward Blore. The foundations were started in 1839 but the building was not completed until 1846 (Fig. 1). The formal landscaped gardens were set out while the house was being built in the early 1840 s, with further developments over the next 50 years. Landscaping included terrace gardens constructed by William Andrews Nesfield (Fig. 1), who started work on the gardens in 1846 . By 1857, there were 6 terraces, separated by stone balustrades, and linked with steps and gravel paths. The top two terraces were set out in a Parterre en Broderie style. A croquet lawn and tennis court were built close to the terraces. To the south lay landscaped parkland and a boating lake. The lake was enlarged by 1875 and featured an island grotto accessible by a footbridge.

To the west of the terraces, woodland separated the grounds of the New Hall from the gardener's cottage and kitchen gardens. The 11 acre walled kitchen gardens were laid out in the early 1840 s to provide vegetables, fruit and flowers to the residents of the New Hall. The perimeter red-brick walls were heated by flues using the Trentham wall case design, to create a warmer micro-climate for the fruit trees grown against them. Glasshouses grew cucumbers, melons, grape vines and peach trees. The head gardener's cottage, built in 1834, was also designed by Edward Blore, while The Bothy was erected in the late 19th century to house unmarried gardeners. A boiler in the cellar of the Bothy provided heating to the kitchen garden glasshouses: its chimney is the most prominent surviving feature of the estate. Queen Victoria visited the hall twice, in October 1851 and June 1857. On her second visit, whilst attending the Art Treasures Exhibition, she planted

Sequoiadendron giganteum on the lawn of the New Hall in memory of the Duke of Wellington, but the tree did not thrive and was not replaced.

After the New Hall was abandoned by the Earls of Ellesmere in 1914, the gardens fell into disrepair, with the formal gardens becoming overgrown. During World War I, John Egerton, 4th Earl of Ellesmere lent the hall to the British Red Cross, and it was used as a hospital for injured soldiers. The grand rooms of the New Hall were used as wards, with food provided by the kitchen gardens with the terraced gardens and parkland used for recreation. The hospital closed in 1919. In 1920, death duties led the 4th Earl to start auctioning off various items of furniture and fittings from the New Hall: the library, and surplus furniture were sold at auction in April 1921. In 1923, the Worsley estate including the New Hall was sold to Bridgewater Estates Limited, a group of Lancashire businessmen, but their grand plans came to nothing. During World War II, the War Office requisitioned parts of the New Hall and the grounds. The 2nd and 8th Battalions of the Lancashire Fusiliers occupied the site in 1939 and 1940, with around 100 troops based there, using the Hall's basements as air raid shelters, and digging training trenches in the grounds. In 1941 and 1942 the 42nd and 45th County of Lancaster Home Guard Battalions used the site, practising street fighting in the hall, and storehouses for explosives were constructed in the grounds. In September 1943, a fire badly damaged the top floor of the New Hall. The building had suffered during the military occupation, with windows broken and interior furnishings used for firewood. The house was also suffering from dry rot and subsidence due to mining. Calls for tenders to demolish the building were sent out in 1944 and by 1949 the hall had been demolished to ground level, with debris used to fill in the basements. 

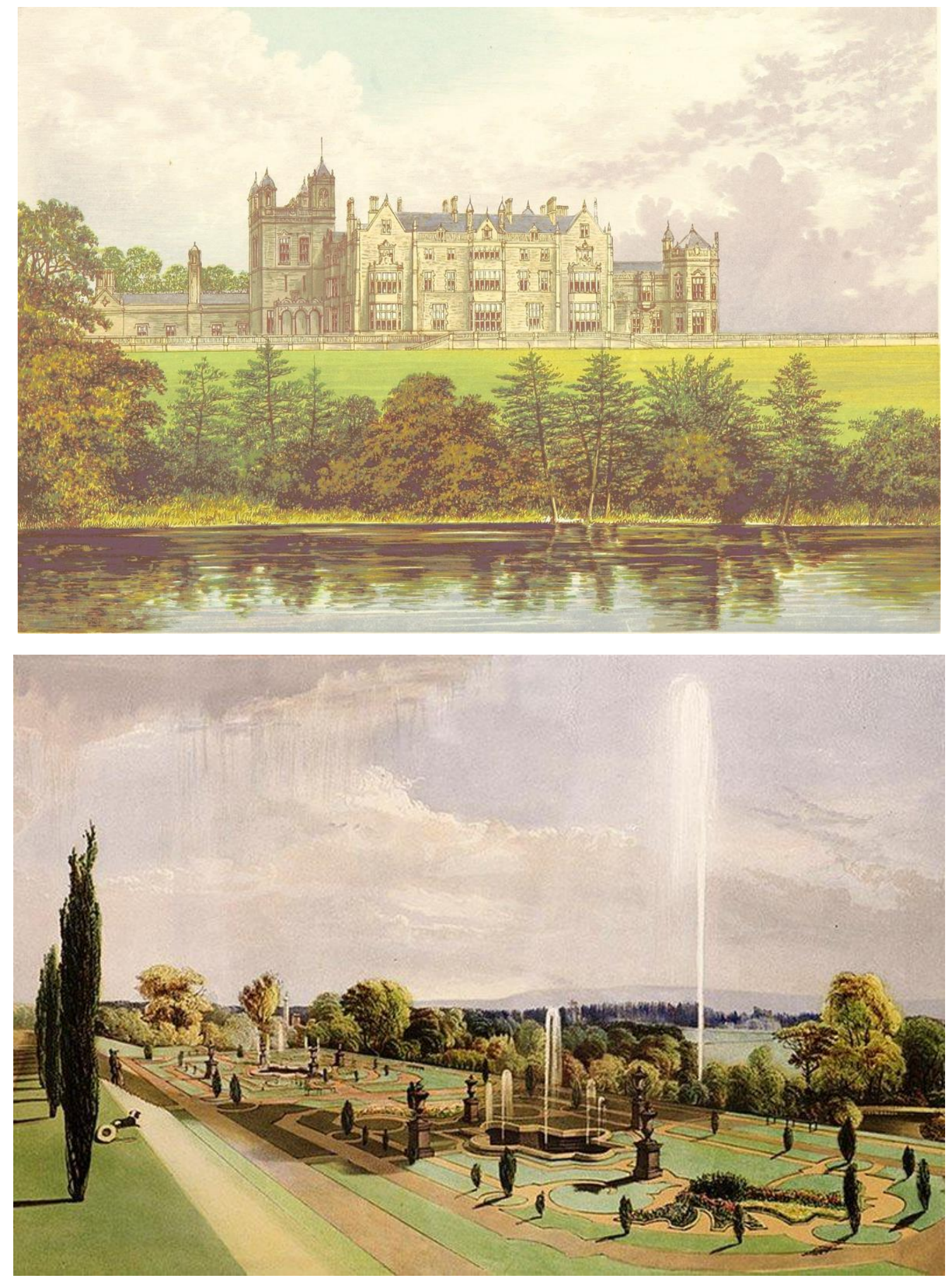

Figure 1. Worsley New Hall (above) was completed in 1846 after 7 years in construction. The formal gardens (below) were designed by Nesfield

Between 1943 and 2016, the woodland was used by generations of boys as an 800-space, 22 acre Scout Camp known as Middlewood. In 1948, the Worsley New Hall Gardens, the Bothy, Garden Cottage and land adjoining comprising 12 acres 
were all sold to Messrs Herbert Harris Cunliffe and Richard Cunliffe, for $£ 6,000$. At this point Worsley Hall Nurseries and Garden Centre was established.

In 1951, the War Office again requisitioned part of the New Hall site and built a reinforced concrete bunker where the servants' wing had been, along with two antiaircraft radar masts. In 1956, the War Office purchased the site of the bunker and it was used by the Royal Navy as a food store. In 1961, the bunker was sold to Salford Corporation, and was used by them and Lancashire County Council as a control centre. In 1968, ownership of the bunker passed to Greater Manchester Fire Service; in 1985 they leased it to a local gun club as a shooting range.

The site of the New Hall and gardens remained in the ownership of Bridgewater Estates Ltd until 1984 when the company was acquired by Peel Holdings, now Peel Land and Property. Worsley Hall Nurseries and Garden Centre continued in business until Peel Holdings bought the Kitchen Garden, Garden Cottage and other buildings in 2008. Over the years there had been various ideas about how the site could be regenerated and put to new use, including a racecourse, hotel and spa.

\section{RHS Involvement at the site}

The Director General of the Royal Horticultural Society, Sue Biggs, first visited the site in January 2015 to assess its potential as a location for the RHS's fifth garden. After extensive deliberations, the proposal by RHS Council to develop the fifth RHS Garden at Worsley was announced in October 2015, with the intention of calling it RHS Bridgewater. Planning approval for the development was granted in April 2017 and the Secretary of State signed off the development in June 2017. This enabled completion and exchange of lease agreements between Salford City Council, the RHS and Peel Holdings in July 2017.

Phase 1 of the development involved the restoration of the historic 11-acre walled garden, following a master plan drawn up by Tom Stuart-Smith (Fig. 2). A Chinese Streamside Garden winding through Middle Wood will link a new lake (Worsley Water) to the restored original lake (Ellesmere Water). A new Welcome Building, facing east across Worsley Water includes an events space, a learning centre, offices, café, shop and plant centre. Community gardening projects, developed with and for local people and organisations, are an integral part of the plan.

The aim of this paper is to document the vascular plants present on the site before and during the construction of the new garden, as a baseline for understanding future changes in plant biodiversity. Most of these changes will be a consequence of deliberate horticultural introductions, but some will be legacy effects, and others will be unplanned botanical incursions. The description of the flora is presented in three sections: the species that were growing on the site before its purchase by RHS; the plants exposed during the construction phase, concentrating on the species that were present in the soil seed bank; and postconstruction landscaping, emphasising those areas that were sown or turfed with commercial wildflower mixtures. The main horticultural planting and the development of the arboretum will be documented in later publications. 


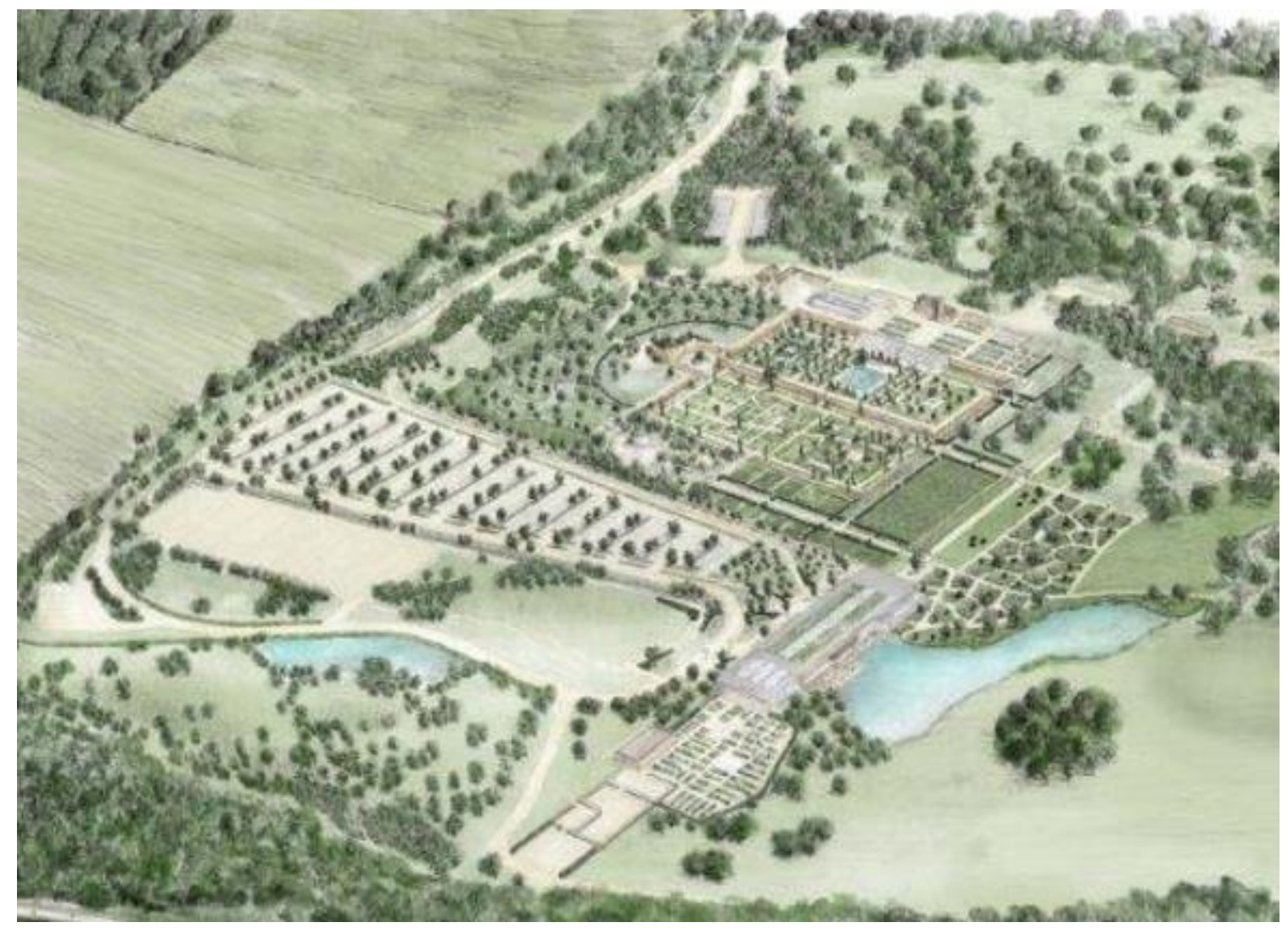

Figure 2. The Walled Garden as planned by Tom Stuart-Smith involves a Paradise Garden with Lily Pond, a Kitchen Garden, with Community Gardens to the south (centre of picture). Trial beds were to be laid out between the north wall and The Bothy (top of picture). Two new lakes were built: Worsley Water (right) with the adjacent Welcome Building and Retail Area and Moss Basin (left)

\section{Methods}

The study area comprises 63 ha, as shown in Fig. 3. The boundaries of RHS Bridgewater are defined on the north by Leigh Road and on the south by the Bridgewater Canal. The eastern boundary follows the edge of the slip road of Junction 13 of the M60 motorway, and the western boundary runs from Leigh Road south to the Canal.

The site was surveyed for vascular plants on 9 March and 1 September 2016 (pre-purchase), 1 June 2017 (pre-soil-stripping), 10 September 2018 (topsoil mounds), 15 August and 25 September 2019 (topsoil mounds) and 11 July 2020 (post-construction). Comprehensive species lists were made for each plant community, noting the dominant, abundant, frequent, occasional and rare species (dafor; Tansley, 1911), but detailed assessments of plant cover were not undertaken. Nomenclature follows Stace (2019). 


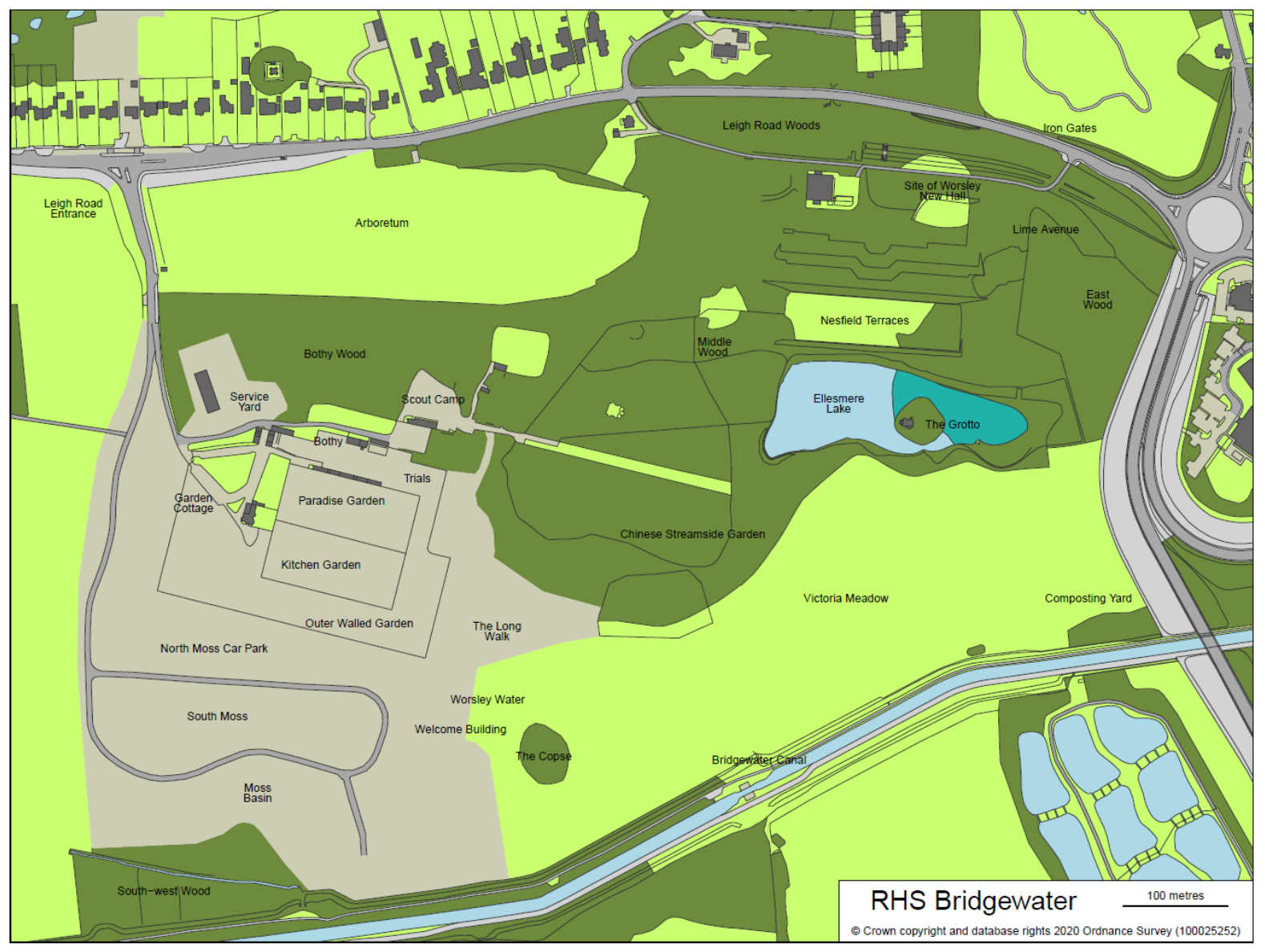

Figure 3. Plan of RHS Bridgewater in 2020. The two principal grasslands, Arboretum and Victoria Meadow are in light green. Existing woodland and scrub are in dark green. The main construction sites (2017-2020) are in grey. A new vehicle entrance onto Leigh Road, controlled by traffic lights, was completed in 2018, funded by Salford Council

\section{Results}

The flora when the site was purchased: 1) semi-natural habitats

Woodland - The main block of woodland comprised East Wood, Leigh Road Woods, Middle Wood and Bothy Wood and represents a species-poor remnant of W10 (Rodwell, 1991a), with the canopy dominated by self-sown Acer pseudoplatanus and the shrub layer by thickets of Rhododendron ponticum naturalised from rootstocks planted in the late $19^{\text {th }}$ century to support choice cultivars as grafts. The dense shade excluded all ground flora from much of the area. The composite species list is shown in Table 1a, where the most conspicuous ground-layer plants were Dryopteris dilatata and $D$. filix-mas (Table 1a). For such a grand garden (Brookes, 1857) there is a surprising lack of ornamental conifers and veteran native trees. 
Table 1. The flora of (a) woodland, (b) scrub and (c) grassland at RHS Bridgewater at the time of purchase in 2017. Frequency for each community is scored from $n=27$ (woodland), $n=19$ (scrub) and $n=18$ (grassland). Species seen in 2 or more of the samples appear in the table. The footnote lists species recorded from a single sample in each community type

\section{a) woodland}

Acer pseudoplatanus

Dryopteris dilatata

Quercus robur

Carex remota

Fagus sy/vatica

Geum urbanum

Rhododendron ponticum

Fraxinus excelsior

Tilia $x$ europaea

Betula pubescens

Crataegus monogyna

Dryopteris filix-mas

Ilex aquifolium

Juncus effusus

Silene dioica

Ranunculus repens

Rubus idaeus

Rumex sanguineus

Sambucus nigra

Urtica dioica

Cardamine flexuosa

Circaea lutetiana

Poa trivialis

Digitalis purpurea

Impatiens glandulifera

\begin{tabular}{ccl} 
dafor & $\begin{array}{c}\text { \% } \\
\text { frequency }\end{array}$ & \multicolumn{1}{c}{ scrub } \\
d & 100 & Dactylis glomerata \\
f & 92 & Arrhenatherum elatius \\
o & 73 & Holcus lanatus \\
Id & 65 & Quercus robur \\
o & 65 & Rumex obtusifolius \\
f & 58 & Acer pseudoplatanus \\
Id & 58 & Heracleum sphondylium \\
f & 54 & Lolium multiflorum \\
f & 54 & Poa trivialis \\
f & 50 & Ranunculus acris \\
o & 50 & Urtica dioica \\
f & 50 & Betula pubescens \\
f & 50 & Galium aparine \\
f & 50 & Ranunculus repens \\
f & 50 & Salix cinerea subsp. oleifolia \\
f & 42 & Alopecurus pratensis \\
f & 42 & Chamerion angustifolium \\
f & 42 & Lolium perenne \\
f & 42 & Epilobium hirsutum \\
Id & 42 & Salix caprea subsp. caprea \\
f & 35 & Sambucus nigra \\
la & 35 & Silene dioica \\
f & 35 & Betula pendula \\
f & 31 & Cirsium arvense \\
la & 31 & Crataegus monogyna \\
& &
\end{tabular}

dafor
Id
Id
ld
a
a
a
a
Id
a
a
ld
a
a
a
a
f
la
f
f
f
f
f
f
f
f

c) grassland $\%$
frequency

100 Rumex obtusifolius

69 Dactylis glomerata

69 Holcus lanatus

69 Lolium multiflorum

69 Ranunculus acris

63 Ranunculus repens

63 Arrhenatherum elatius

63 Lolium perenne

63 Poa trivialis

63 Cirsium arvense

63 Alopecurus geniculatus

56 Cerastium fontanum

56 Taraxacum officinale agg.

56 Alopecurus pratensis

56 Anthoxanthum odoratum

50 Bromus hordeaceus

50 Cirsium vulgare

50 Cynosurus cristatus

44 Phleum pratense

44 Agrostis stolonifera

44 Cerastium glomeratum

44 Equisetum arvense

38

38

38

\section{Heracleum sphondylium}

Holcus mollis

Juncus effusus

\begin{tabular}{cc} 
dafor & $\begin{array}{c}\% \\
\text { frequency }\end{array}$ \\
a & 100 \\
a & 83 \\
a & 83 \\
d & 83 \\
a & 83 \\
a & 75 \\
a & 67 \\
o & 67 \\
f & 58 \\
f & 50 \\
la & 42 \\
f & 42 \\
a & 42 \\
f & 25 \\
f & 25 \\
f & 25 \\
f & 25 \\
f & 25 \\
f & 25 \\
la & 17 \\
f & 17 \\
o & 17 \\
o & 17 \\
la & 17 \\
la & 17 \\
& \\
\hline
\end{tabular}




\begin{tabular}{|c|c|c|c|c|}
\hline Asplenium scolopendrium & 0 & 31 & Cynosurus cristatus & $f$ \\
\hline Veronica montana & 0 & 31 & Dryopteris filix-mas & $f$ \\
\hline Athyrium filix-femina & 0 & 27 & Impatiens glandulifera & $f$ \\
\hline Heracleum sphondylium & 0 & 27 & Rhododendron ponticum & Id \\
\hline Carex pendula & 0 & 23 & Salix $x$ reichardtii & $f$ \\
\hline Castanea sativa & 0 & 23 & Trifolium repens & $f$ \\
\hline Dactylis glomerata & 0 & 23 & Cerastium glomeratum & $f$ \\
\hline Epilobium montanum & 0 & 23 & Equisetum arvense & $f$ \\
\hline Galium aparine & 0 & 23 & Fagus sy/vatica & 0 \\
\hline Phalaris arundinacea & 0 & 23 & Fraxinus excelsior & 0 \\
\hline Jacobaea vulgaris & 0 & 23 & Phleum pratense & 0 \\
\hline Solanum dulcamara & 0 & 23 & Plantago lanceolata & 0 \\
\hline Alnus glutinosa & 0 & 19 & Pteridium aquilinum & la \\
\hline Betula pendula & 0 & 19 & Jacobaea vulgaris & $f$ \\
\hline Epilobium hirsutum & 0 & 19 & Agrostis stolonifera & $f$ \\
\hline Hyacinthoides non-scripta & 0 & 19 & Alopecurus geniculatus & la \\
\hline Salix caprea subsp. caprea & la & 19 & Bromus hordeaceus & 0 \\
\hline Scrophularia nodosa & 0 & 19 & Plantago major & 0 \\
\hline Aesculus hippocastanum & 0 & 15 & Trifolium pratense & 0 \\
\hline Ajuga reptans & 0 & 15 & Vicia cracca & 0 \\
\hline Holcus lanatus & 0 & 15 & Alliaria petiolata & la \\
\hline Larix $x$ marschlinsii & Id & 15 & Alnus glutinosa & 0 \\
\hline Plantago major & 0 & 15 & Anthoxanthum odoratum & $f$ \\
\hline Pteridium aquilinum & 0 & 15 & Anthriscus sylvestris & $f$ \\
\hline Quercus petraea & $r$ & 15 & Cerastium fontanum & $f$ \\
\hline Ranunculus acris & 0 & 15 & Juncus effusus & $f$ \\
\hline Rumex obtusifolius & 0 & 15 & Persicaria maculosa & 0 \\
\hline Agrostis capillaris & 0 & 12 & Phalaris arundinacea & 0 \\
\hline Alliaria petiolata & 0 & 12 & Poa annua & 0 \\
\hline Corylus avellana & 0 & 12 & Acer campestre & 0 \\
\hline Deschampsia cespitosa & 0 & 12 & Acer platanoides & 0 \\
\hline
\end{tabular}

$\begin{array}{lll}\text { Plantago major } & 0 & 17 \\ \text { Jacobaea vulgaris } & 0 & 17 \\ \text { Trifolium repens } & 0 & 17 \\ \text { Urtica dioica } & 0 & 17 \\ \text { Vicia sepium } & 0 & 17\end{array}$




\begin{tabular}{|c|c|c|c|c|c|}
\hline Equisetum arvense & 0 & 12 & Aesculus hippocastanum & 0 & 13 \\
\hline Glyceria maxima & $r$ & 12 & Betula $x$ aurata & 0 & 13 \\
\hline Hedera helix & 0 & 12 & Buddleja davidii & 0 & 13 \\
\hline Holcus mollis & la & 12 & Cardamine flexuosa & 0 & 13 \\
\hline Iris pseudacorus & 0 & 12 & Castanea sativa & 0 & 13 \\
\hline Prunella vulgaris & 0 & 12 & Centaurium erythraea & 0 & 13 \\
\hline Quercus x rosacea & 0 & 12 & Cirsium vulgare & 0 & 13 \\
\hline Salix cinerea subsp. oleifolia & la & 12 & Dryopteris dilatata & 0 & 13 \\
\hline Salix fragilis & 0 & 12 & Epilobium ciliatum & 0 & 13 \\
\hline Salix $x$ reichardtii & 0 & 12 & Reynoutria sachalinensis & $r$ & 13 \\
\hline Stachys sylvatica & 0 & 12 & Festuca rubra & 0 & 13 \\
\hline Tussilago farfara & 0 & 12 & Glyceria fluitans & 0 & 13 \\
\hline Acer platanoides & $r$ & 8 & Holcus mollis & la & 13 \\
\hline Agrostis stolonifera & 0 & 8 & Hypochaeris radicata & 0 & 13 \\
\hline Arrhenatherum elatius & 0 & 8 & Ilex aquifolium & 0 & 13 \\
\hline Betula $x$ aurata & 0 & 8 & Matricaria discoidea & 0 & 13 \\
\hline Chamerion angustifolium & la & 8 & Polygonum aviculare & 0 & 13 \\
\hline Cirsium arvense & 0 & 8 & Populus $x$ canadensis & 0 & 13 \\
\hline Cornus sericea & 0 & 8 & Prunus avium & 0 & 13 \\
\hline Cytisus scoparius & 0 & 8 & Prunus laurocerasus & 0 & 13 \\
\hline Dryopteris affinis & $r$ & 8 & Pulicaria dysenterica & 0 & 13 \\
\hline Dryopteris borreri & $r$ & 8 & Rubus idaeus & 0 & 13 \\
\hline Reynoutria japonica & If & 8 & Rumex acetosa & 0 & 13 \\
\hline Lapsana communis & 0 & 8 & Sagina procumbens & 0 & 13 \\
\hline Lolium perenne & 0 & 8 & Salix alba & 0 & 13 \\
\hline Mercurialis perennis & la & 8 & Salix fragilis & 0 & 13 \\
\hline Phragmites australis & la & 8 & Salix viminalis & 0 & 13 \\
\hline Picea abies & 0 & 8 & Sorbus aucuparia & 0 & 13 \\
\hline Polystichum setiferum & $r$ & 8 & Tilia x europaea & 0 & 13 \\
\hline Sorbus aucuparia & 0 & 8 & Tussilago farfara & 0 & 13 \\
\hline Taxus baccata & la & 8 & Vicia sepium & 0 & 13 \\
\hline
\end{tabular}


Species recorded in just 1 woodland sample

Acer platanoides 'Crimson King', Acer saccharinum, Acorus calamus, Anisantha sterilis, Anthriscus sylvestris, Aquilegia vulgaris, Arctium minus, Arctium nemorosum, Arum maculatum, Astrantia major, Baptisia australis var. minor, Brachypodium sylvaticum, Bromus hordeaceus, Buddleja davidii, Callitriche stagnalis, Carex muricata subsp. pairae, Centaurea debeauxii, Centaurium erythraea, Cerastium fontanum, Chrysosplenium oppositifolium, Cirsium palustre, Cirsium vulgare, Cornus sanguinea, Crepis vesicaria subsp. taraxacifolia, Deschampsia cespitosa subsp. cespitosa, Epilobium ciliatum, Epilobium palustre, Epilobium parviflorum, Euonymus europaeus, Festuca rubra, Galanthus nivalis, Galium saxatile, Geranium dissectum, Geranium molle, Geranium robertianum, Glechoma hederacea, Glyceria fluitans, Juncus conglomeratus, Larix decidua, Lemna minor, Ligustrum ovalifolium, Lotus corniculatus, Lysimachia nemorum, Mahonia aquifolium, Oenothera glazioviana, Oxalis acetosella, Pentaglottis sempervirens, Persicaria maculosa, Plantago lanceolata, Poa annua, Poa nemoralis, Polygonatum x hybridum, Quercus ilex, Quercus rubra, Ribes rubrum, Rubus fruticosus agg., Salix alba, Sonchus asper, Symphoricarpos x chenaultii, Symphytum grandiflorum, Tilia cordata, Tragopogon pratensis subsp. minor, Trifolium dubium, Typha latifolia, Veronica hederifolia subsp. hederifolia, Veronica serpyllifolia, Vicia sepium

Species recorded in just 1 scrub sample

Acer pseudoplatanus 'Atropurpureum', Aegopodium podagraria, Aesculus carnea, Agrostis capillaris, Anisantha sterilis, Arctium minus, Arum maculatum, Calystegia sepium, Carduus crispus, Carex nigra, Carex pendula, Centaurea debeauxii, Chamaecyparis lawsoniana, Crepis capillaris, Cytisus scoparius, Epilobium montanum, Epilobium parviflorum, Ervilia hirsuta, Fagus sylvatica 'Atropurpurea', Festuca ovina, Fragaria vesca, Galium album, Hieracium sect. Hieracium, Humulus lupulus, Hyacinthoides non-scripta, Juncus inflexus, Juncus tenuis, Ligustrum sp., Lotus corniculatus, Luzula campestris, Medicago Iupulina, Picea sitchensis, Pilosella aurantiaca subsp. carpathicola, Potentilla erecta, Prunella vulgaris, Quercus cerris, Rubus fruticosus agg., Rumex acetosella, Rumex sanguineus, Salix x sepulcralis, Scrophularia nodosa, Stachys sylvatica, Torilis japonica, Trifolium dubium, Ulex europaeus, Ulmus glabra, Veronica serpyllifolia, Vicia sativa subsp. segetalis

Species recorded in just 1 grassland sample

Cardamine pratensis, Chamerion angustifolium, Elytrigia repens, Epilobium parviflorum, Ervilia hirsuta, Galium saxatile, Glyceria fluitans, Juncus bufonius, Lotus corniculatus, Petasites hybridus, Phalaris arundinacea, Rumex acetosa, Salix cinerea subsp. oleifolia, Sambucus nigra, Stellaria alsine, Thymus drucei, Vicia cracca 
A second, much smaller fragment of naturally regenerated wet woodland occupies the extreme south-wester corner of the estate, bordering the Bridgewater Canal. It is dominated by Acer pseudoplatanus, with Athyrium filix-femina, Crataegus monogyna, Digitalis purpurea, Dryopteris dilatata, Epilobium hirsutum, Fagus sy/vatica, Fraxinus excelsior, Geum urbanum, Glyceria fluitans, Heracleum sphondylium, Ilex aquifolium, Impatiens glandulifera, Lemna minor, Persicaria maculosa, Poa trivialis, Quercus robur, Ranunculus acris, Ranunculus repens, Rhododendron ponticum, Rubus idaeus, Rumex sanguineus, Sambucus nigra, Silene dioica, Solanum dulcamara, Sorbus aucuparia, Stachys sylvatica, Tilia x europaea and Urtica dioica.

Certainly or probably planted species persisting within the main block of woodland were Acer platanoides, Acer saccharinum, Aesculus hippocastanum, Aquilegia vulgaris, Castanea sativa, Fagus sy/vatica, a plantation of Larix $X$ marschlinsii, Ligustrum ovalifolium, Picea abies, Pinus strobus, Polygonatum $x$ hybridum, Polystichum setiferum, Populus $x$ canadensis, Quercus ilex, $Q$. petraea, $Q$. $x$ rosacea, Reynoutria japonica, Rhododendron spp., Symphoricarpos $x$ chenaultii, Symphytum grandiflorum and an avenue of Tilia $x$ europaea.

Grassland - There were two extensive grasslands: Victoria Meadow dominates the south-eastern quarter of the estate, and The Arboretum occupies the north-western corner. Both were similar in their botanical composition (MG7; Rodwell, 1992): they represent ultra-species-poor hay meadows, sown to Lolium mulitflorum and heavily fertilized each year. Other than Rumex obtusifolius, Ranunculus spp. and a scattering of thistles, there were very few dicots (Table 1c). Damper patches within the meadow were dominated by Juncus effusus with Alopecurus geniculatus, Agrostis stolonifera, Glyceria fluitans, Phalaris arundinacea and Stellaria alsine.

Scrub - A zone of scrub ranging between 5 and $20 \mathrm{~m}$ wide surrounded Victoria Meadow and Arboretum Meadow (Fig. 3). The flora (Table 1b) was intermediate between woodland and grassland, and while the woodland component was reduced in species-richness, the grassland component had more species (both of grasses and forbs; MG1, Rodwell 1992) than the adjacent meadow, dominated as this was by Lolium multiflorum. In damper areas, sallow (Salix cinerea subsp. oleifera and hybrids) and Impatiens glandulifera were conspicuous.

Wetland - There were small patches of wetland all along the southern boundary, next to the Bridgewater canal, with a Reedmace swamp (S12; Rodwell 1995) in the south-eastern corner. The most extensive wetland was at the eastern end of the man-made Ellesmere Lake which had been a focal feature of the original garden, at the foot of the steep terraces, south of the grand house. The eastern half of the lake had long-since silted up, and the former lake bed supported a wet woodland, with Acer pseudoplatanus, Alnus glutinosa, Athyrium filix-femina, Betula pubescens, Carex pendula, Crataegus monogyna, Dactylis glomerata, Dryopteris dilatata, Dryopteris filix-mas, Fagus sylvatica, Impatiens glandulifera, Phalaris arundinacea, Phragmites australis, Quercus robur, Ribes rubrum, Rumex sanguineus, Salix X fragilis, Solanum dulcamara and Urtica dioica. The ground layer was dominated by Carex remota (as in W2; Rodwell 1991a). 
The Moss - Nothing remained of the Sphagnum mires (M18; Rodwell 1991b) that once dominated the lower ground on the south of the site (the grey area in Fig. 3) which would have supported species like Erica tetralix, Andromeda polifolia, Drosera intermedia, D. anglica, Rhynchospora alba, Myrica gale and Osmunda regalis (Savidge et al., 1963). These mires were probably drained in the mid $18^{\text {th }}$ century before the canal was built. The ghost of the mire survives in the form of black, peaty soils underlying the improved grasslands that stretch from South Moss to Victoria Meadow.

The Lake - Before it was drained for dredging (2018) and refurbishment of the stonework (2019), the surface of the boating lake (now re-named Ellesmere Lake) was completely dominated by Nymphoides peltata. There were isolated patches of Nuphar lutea and Nymphaea alba and pockets of Lemna minor, but there was very little marginal vegetation.

The flora when the site was purchased: 2) Built-up areas

The Walled Garden - In 2016 this was a head-high wilderness of Pteridium aquilinum, Rubus fruticosus agg. with various species and hybrid Salix, set amongst derelict greenhouses and broken-down brick walls. There were scattered individuals of Acer platanoides, Acer platanoides 'Crimson King', Aesculus carnea, Alnus glutinosa, Anemone x hybrida, Arrhenatherum elatius, Asplenium scolopendrium Betula pendula, Buddleja davidii, Calystegia sepium, Carex pendula, Cercis siliquastrum, Chamerion angustifolium, Cirsium vulgare, Crocosmia x crocosmiiflora, Dryopteris filix-mas, Epilobium hirsutum, Equisetum arvense, Eupatorium cannabinum, Fallopia baldschuanica, Geranium robertianum, Holcus mollis, Hypericum perforatum, Hypochaeris radicata, Juglans regia, Lapsana communis, Lobelia erinus, Mentha spicata, Mentha x piperita, Mentha x villosa, Oenothera biennis, Origanum vulgare, Parthenocissus quinquefolia, Parthenocissus tricuspidata, Phragmites australis, Prunella vulgaris, Salix caprea subsp. caprea, S. cinerea subsp. oleifolia, S. x fragilis, S. viminalis, S. x reichardtii, Senecio vulgaris, Sonchus oleraceus, Symphytum x uplandicum, Thuja plicata, Tussilago farfara, Vicia sativa subsp. segetalis and Vinca major.

The Former Terraced Gardens - This area, once dominated by immaculately manicured terraces of formal bedding, with fountains and ornate stonework was overgrown waste ground. Between 2011 and 2014 Salford University and Peel Holdings carried out a joint project involving an archaeological excavation of the north of the area to expose the foundations and cellars of Worsley New Hall (Fig. 4) The area revegetated over the period 2014-2017 in a typical waste-ground secondary succession and by 2020 was a dense scrub dominated by Buddleja davidii and Salix spp. and hybrids. Species restricted to this area, or reaching their peak abundance here, were Carex elata 'Aurea', Centaurea debeauxii, Centaurium erythraea, Cirsium vulgare, Cytisus scoparius, Epilobium parviflorum, Erigeron canadensis, E. floribundus, Ervilia hirsuta, Heracleum sphondylium, Hieracium Sect. Hieracium, Juncus tenuis, Prunella vulgaris, Pulicaria dysenterica, Jacobaea vulgaris, Sorbus aucuparia, Trifolium repens and Tussilago farfara. 


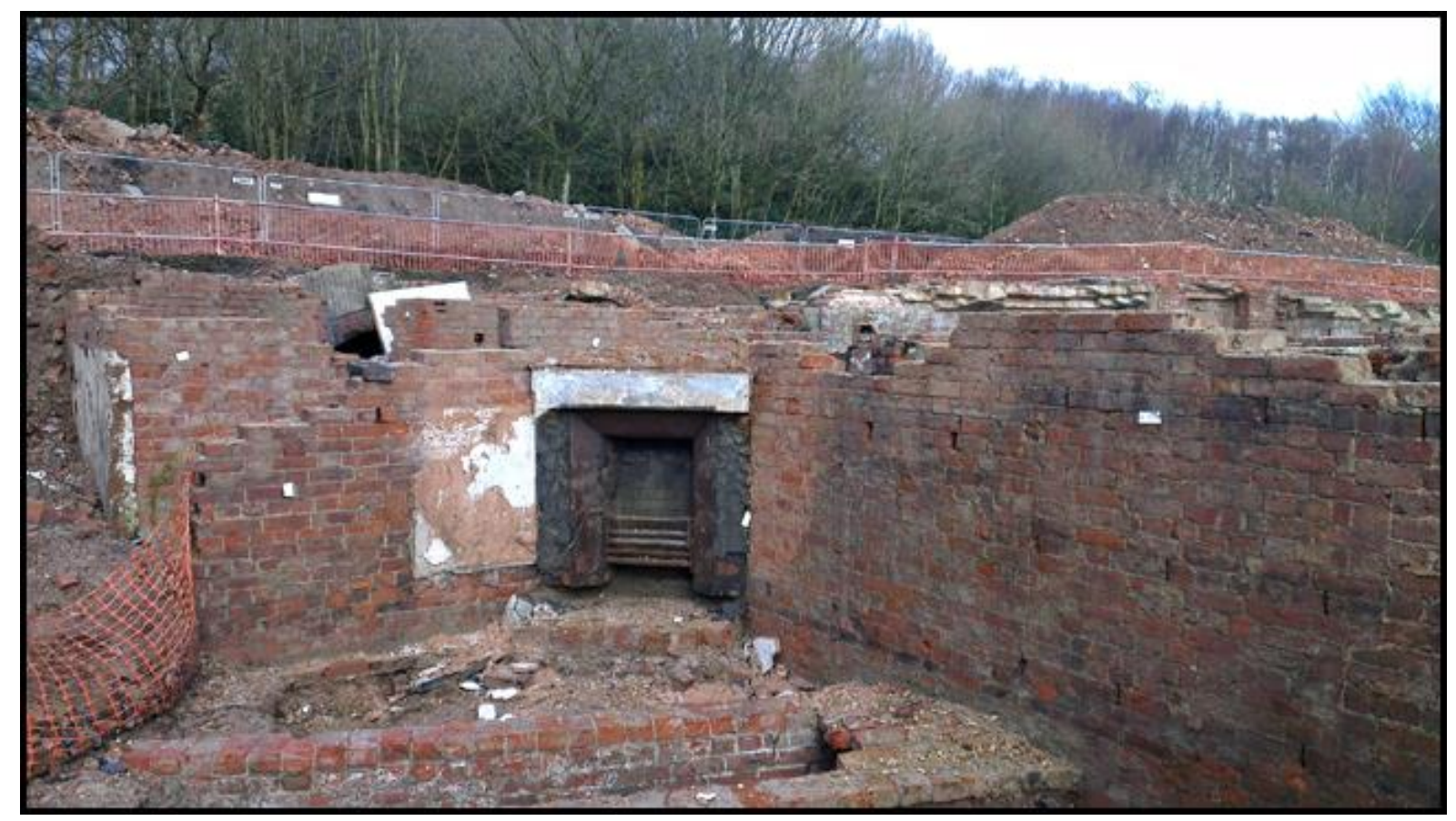

Figure 4. The cellars of Worsley New Hall were excavated during an archaeological dig between 2011-14. After infill, the site was left as open waste ground 2014-2020 to undergo secondary succession to Buddleja scrub

The Scout Camp - The Scout Masters maintained open areas for camping, games and camp fires, as well as for woodland adventures. From time to time, they planted trees and ornamental shrubs, and several of these survived and have been preserved (e.g. Metasequoia glyptostroboides). The area was a mosaic of woodland, grassy clearings and shrubberies, with Acer platanoides, A. pseudoplatanus, Aesculus hippocastanum, Agrostis capillaris, A. stolonifera, Alliaria petiolata, Alnus glutinosa, Alopecurus geniculatus, Anisantha sterilis, Anthriscus sylvestris, Aquilegia vulgaris, Arabidopsis thaliana, Arrhenatherum elatius, Athyrium filix-femina, Bellis perennis, Berberis darwinii, Betula pendula, B. pubescens, B. x aurata, Cardamine flexuosa, C. hirsuta, C. pratensis, Carex pendula, C. remota, Cerastium fontanum, $C$. glomeratum, Chenopodium album, Cirsium arvense, Corylus avellana, Crataegus monogyna, Crepis vesicaria subsp. taraxacifolia, Crocosmia paniculata, Dactylis glomerata, Dryopteris dilatata, D. filix-mas, Epilobium ciliatum, E. hirsutum, E. montanum, E. parviflorum, Erigeron canadensis, Escallonia macrantha, Euonymus europaeus, Festuca rubra, Fraxinus excelsior, Fuchsia magellanica, Galium aparine, G. saxatile, Geranium dissectum, G. robertianum, Geum urbanum, Heracleum sphondylium, Holcus lanatus, H. mollis, Hyacinthoides $x$ massartiana, Hypericum 'Hidcote', H. hircinum, Ilex aquifolium, Juncus bufonius, J. effusus, Lamiastrum galeobdolon subsp. argentatum, Lapsana communis, Lepidium didymum, Leycesteria formosa, Lolium perenne, Lotus corniculatus, Lysimachia nemorum, Paeonia officinalis, Persicaria maculosa, Picea abies, Pinus strobus, Plantago lanceolata, $P$. major, Platanus $x$ hispanica, Poa annua, P. pratensis, P. trivialis, Polygonum aviculare, Populus nigra 'Italica', Prunella vulgaris, Prunus avium, P. cerasifera 'Nigra', P. laurocerasus, Pulicaria dysenterica, Quercus robur, Ranunculus acris, $R$. repens, Reynoutria japonica, Rhododendron ponticum, Ribes uva-crispa, Rubus 
idaeus, Rumex acetosa, $R$. crispus, $R$. obtusifolius, $R$. sanguineus, Sagina procumbens, Salix caprea subsp. caprea, $S$. cinerea subsp. oleifolia, $S$. x reichardtii, Sambucus nigra, Scrophularia nodosa, Jacobaea vulgaris, Silene dioica, Sonchus asper, S. oleraceus, Sorbus intermedia, Stachys sylvatica, Stellaria media, S. alsine, Tellima grandiflora, Trifolium dubium, Trifolium pratense, Trifolium repens, Urtica dioica, Veronica persica, V. serpyllifolia and Vinca minor.

The Garden Centre - The buildings to the north and west of the Walled Garden were used as a Garden Centre, and supported an essentially urban flora, with tarmac, concrete, lawns, brickwork and waste ground with Acer pseudoplatanus, Agrostis capillaris, Alliaria petiolata, Amaranthus caudatus, Anisantha sterilis, Antirrhinum majus, Arabidopsis thaliana, Arum maculatum, Asplenium ruta-muraria, A.

scolopendrium, A. trichomanes subsp. quadrivalens, Bellis perennis, Betula pendula, Buddleja davidii, Calendula officinalis, Calystegia sepium, Capsella bursa-pastoris, Cardamine hirsuta, Cerastium fontanum, Chenopodium album, C. rubrum, Cirsium arvense, Cirsium vulgare, Cornus kousa 'China Girl', Crataegus arnoldiana, $C$. monogyna, Crepis vesicaria subsp. taraxacifolia, Cytisus scoparius, Descurainia sophia, Dryopteris filix-mas, Epilobium ciliatum, E. hirsutum, E. montanum, E. parviflorum, Equisetum arvense, Erigeron canadensis, Erophila verna, Ervilia hirsuta, Eupatorium cannabinum, Euphorbia characias 'Wilcott', Fallopia baldschuanica, Festuca rubra, Foeniculum vulgare, Galium aparine, G. odoratum, Geranium robertianum, G. robertianum, G. rotundifolium, G. x magnificum, G. x oxonianum, Geum urbanum, Griselinia littoralis 'Variegata', Hedera colchica, H. helix, Heracleum sphondylium, Holcus lanatus, Ilex aquifolium, Lapsana communis, Lepidium didymum, Lolium multiflorum, Lolium perenne, Lonicera x purpusii, Lysimachia nummularia, Magnolia x soulangiana, Malus domestica, Nerine bowdenii, Osteospermum jucundum, Papaver cambricum, Parthenocissus tricuspidata, Persicaria maculosa, Phuopsis stylosa, Plantago lanceolata, Plantago major, Poa annua, Polygonum aviculare, Polypodium vulgare, Polypogon viridis, Potentilla anserina, Prunella vulgaris, Pyrus communis 'Maiden', Ranunculus acris, Ranunculus repens, Reynoutria japonica, Sagina procumbens, Sambucus nigra, Jacobaea vulgaris, Senecio vulgaris, Sisymbrium officinale, Sonchus asper, Sonchus oleraceus, Sorbus hybrida 'Gibsii', Sorbus aucuparia 'Edulis', Stachys sylvatica, Stipa tenuissima, Thymus vulgaris, Tripleurospermum inodorum, Triticum aestivum, Tropaeolum majus, Urtica dioica, Veronica arvensis and Veronica serpyllifolia.

The flora during construction

Work for the new garden involved stripping $35,000 \mathrm{~m}^{3}$ of topsoil, sub-soil and spoil, with most of the top-soil coming from the south-western corner of the estate, during construction of North and South Moss Car Parks, the Welcome Building and Worsley Water. Removing the topsoil and storing it in the Arboretum and at the eastern end of Victoria Meadow began in spring 2018. The flora of the soil piles was first investigated on 10 September 2018, with follow-up surveys on 25 September 2019 and 11 July 2020.

The seed bank of the black peaty soils of The Moss was sufficiently consistent and distinctive to merit description as a new category of Open Vegetation (Galeopsis speciosa community; Table 2). The early country floras of Cheshire (Warren 1899) and Lancashire (Wheldon \& Wilson, 1907) as well as the metropolitan floras of 
Liverpool (Dickinson 1851) and Manchester (Wood, 1840, Grindon 1859) agree that Galeopsis speciosa was a locally abundant component of the seed bank of root crops on black, peaty soils. Curtis (1777-98) considered it to be "One of the most splendid of our native wild flowers". An early description of this seed bank was by Price Evans (1923) from Carrington Moss, just south of the RiverMersey in Cheshire. Prior to 1886 this had been a well-stocked grouse-moor, over 600 acres in extent, forming part of the estates of the Earl of Stamford. In 1886 the Moss was purchased by the Manchester Corporation to be used primarily as a dumping-ground for town refuse. It was then systematically drained as the first step towards creating valuable agricultural land. Hundreds of thousands of tons of night-soil, with cinders, were dumped on the virgin moss, but after the introduction of modern methods of sanitation this practice was discontinued. Subsequently, street-sweepings were supplemented by sulphate of potash, sulphate of ammonia and super-phosphate. This created a soil that could be worked and tilled in all weathers; it never got too wet and, on the other hand, never too dry (Price Evans, 1923). He described the seed bank as follows: abundant Achillea millefolium, Atriplex patula, Chenopodium album, Elymus repens, Galeopsis speciosa, Persicaria maculosa, Rumex acetosella, Stellaria media, Tussilago farfara, Veronica hederifolia; frequent Capsella bursapastoris, Fallopia convolvulus, Holcus mollis, Mentha arvensis, Myosotis arvensis, Papaver dubium, Plantago major, Poa annua, Poa trivialis, Rorippa palustris, Senecio vulgaris, Sinapis arvensis, Spergula arvensis, Stachys palustris, Symphytum officinale, Trifolium spp., Veronica arvensis; 29 further species were listed as occasional or rare. He observed that "Galeopsis speciosa is perhaps the most conspicuous weed on the arable ground on the Moss, and it can only be held in check by a vigorous or 'smothering' crop" like potato. 
Table 2. Galeopsis speciosa seed bank community: a new Open Vegetation (OV) community

\section{Constant species}

Galeopsis speciosa, Sonchus asper, Galium aparine, Rumex obtusifolius, Persicaria maculosa, Cirsium vulgare.

\section{Physiognamy}

A spring-germinating ruderal community with a diverse, long-lived seed bank producing a dense cover of species-rich vegetation by late summer. Galeopsis speciosa has a strong dormancy that is sufficiently alleviated during the winter to allow germination of only part of a seed batch each spring; hence a stepwise germination pattern occurs over a period of several years (Karlsson et al., 2006).

\section{Habitat}

Peaty soils, of the kind developed during the $18^{\text {th }}$ and $19^{\text {th }}$ centuries on lowland 'mosses' in the north-west of England. Driven by the fashion for agricultural improvement, the bog was drained, then copious quantities of night soil were applied to surface of the peat each year. Today these habitats have black peaty loam soils with a pH around 6.2.

\section{Zonation and Succession}

The community appears following disturbance of the perennial vegetation by ploughing or during construction work. It disappears after 2-4 years of secondary succession, replaced by rank grassland, then scrub.

\section{Distribution}

Not yet documented, but necessarily restricted to the distribution of the nominate species on lowland peaty soils in western Wales, north-west and eastern England, lowland Scotland and Northern Ireland (Fig 5).

\section{Affinities}

Closest to OV13 with Stellaria media, Capsella bursa-pastoris, Chenopodium album, Polygonum aviculare and Senecio vulgaris, but with much higher cover of Persicaria maculosa. Substantial overlap with OV33 but with much lower cover of Poa annua, and Persicaria lapathifolia occasional rather than constant. There is an interesting damp element to this new seed bank with Agrostis stolonifera, Alopecurus geniculatus, Cardamine flexuosa, Epilobium hirsutum, Gnaphalium uliginosum, Impatiens glandulifera, Juncus effusus, Ranunculus sceleratus, Rorippa palustris, Salix cinerea subsp. oleifolia, Stachys palustris and Typha latifolia. 


\section{Floristic Table}

Species

Galeopsis speciosa

Persicaria maculosa

Lolium multiflorum

Urtica dioica

Fallopia convolvulus

Lamium purpureum

Tripleurospermum inodorum

Viola arvensis

Chenopodium album

Cirsium vulgare

Rorippa palustris

Rumex obtusifolius

Sinapis arvensis

Sonchus asper

Stellaria media

Agrostis stolonifera

Capsella bursa-pastoris

Cirsium arvense

Plantago major

Polygonum aviculare

Galeopsis tetrahit

Matricaria discoidea

Cerastium glomeratum

Holcus lanatus

Ervilia hirsuta

Ranunculus repens
Sites (details below)

$\begin{array}{lllllllllllllllll}\text { Frequency } & 1 & 2 & 3 & 4 & 5 & 6 & 7 & 8 & 9 & 10 & 11 & 12 & 13 & 14 & \end{array}$

$\begin{array}{lllllllll}\text { V } & 1 & 1 & 1 & 1 & 1 & 1 & 1 & 1 \\ \text { V } & 1 & 1 & 1 & 1 & 1 & 1 & 1 & 1 \\ \text { IV } & & 1 & 1 & 1 & 1 & 1 & & 1 \\ \text { IV } & 1 & 1 & 1 & 1 & 1 & 1 & 1 & 1 \\ \text { IV } & 1 & & & & 1 & 1 & 1 & 1 \\ \text { IV } & 1 & & & 1 & & 1 & 1 & 1 \\ \text { IV } & & 1 & 1 & 1 & 1 & 1 & 1 & 1 \\ \text { IV } & & 1 & 1 & 1 & & 1 & 1 & 1 \\ \text { IV } & 1 & & & 1 & 1 & 2 & 1 & \\ \text { IV } & 1 & 1 & 1 & 1 & 1 & 1 & 1 & 1 \\ \text { IV } & 1 & & 1 & 1 & & & 1 & 1 \\ \text { IV } & 1 & & 1 & 1 & 1 & 1 & & 1 \\ \text { IV } & 1 & & & 1 & 1 & & 1 & 1 \\ \text { IV } & 1 & 1 & 1 & 1 & 1 & & & 1 \\ \text { IV } & 1 & & & 1 & 1 & 1 & 1 & 1 \\ \text { III } & & & 1 & & & 1 & 1 & 1 \\ \text { III } & 1 & 1 & & & 1 & 1 & 1 & \\ \text { III } & 1 & & 1 & 1 & & 1 & 1 & 1 \\ \text { III } & & 1 & 1 & 1 & 1 & 1 & & 1 \\ \text { III } & & & 1 & 1 & 1 & 2 & & \\ \text { III } & & 1 & & 1 & & & 1 & 1 \\ \text { III } & & & 1 & 1 & 1 & & 1 & 1 \\ \text { III } & & & 1 & 1 & & & & 1 \\ \text { III } & & 1 & 1 & & 1 & & & 1 \\ \text { III } & & & & 1 & & 1 & & 1 \\ \text { III } & & & 1 & 1 & 1 & & 1 & \end{array}$

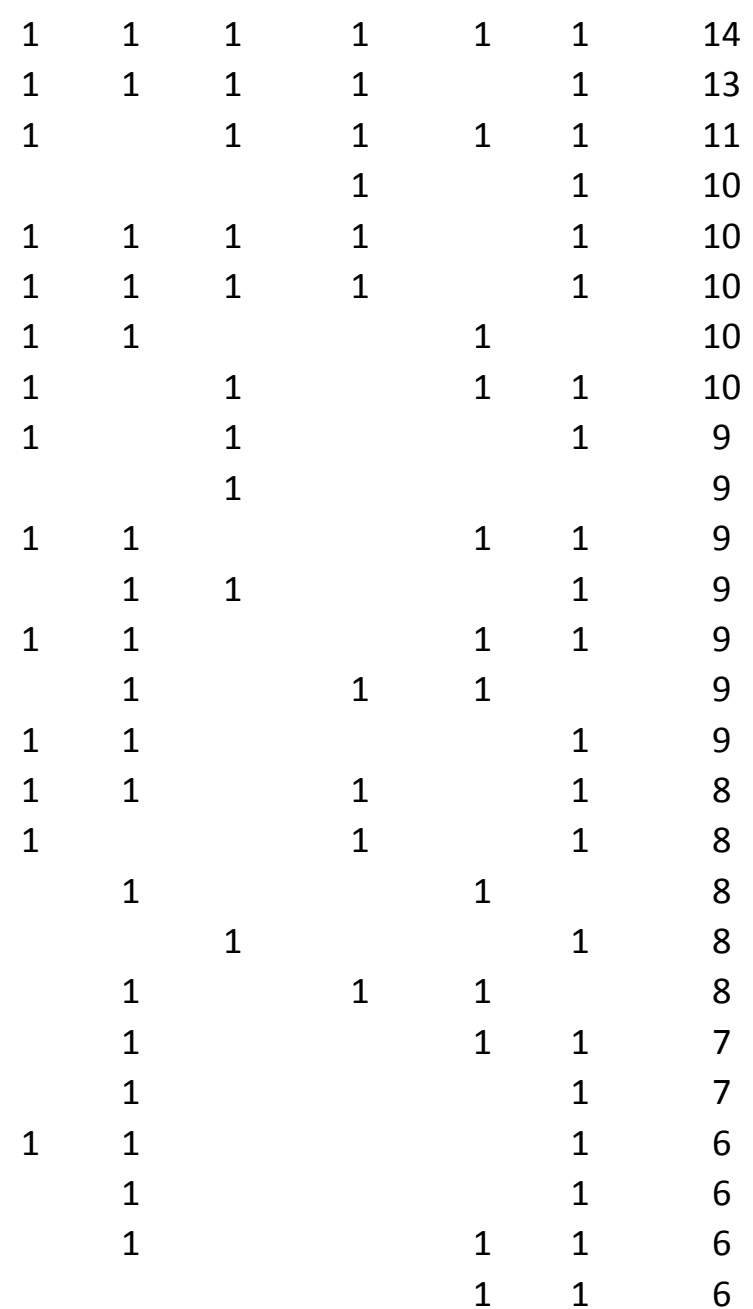


Ranunculus sceleratus

Alopecurus geniculatus

Arrhenatherum elatius

Cerastium fontanum

Elytrigia repens

Epilobium ciliatum

Epilobium hirsutum

Galium aparine

Matricaria recutito

Persicaria lapathifolia

Phleum pratense

Raphanus raphanistrum

Senecio vulgaris

Veronica persica

Atriplex patula

Atriplex prostrata

Brassica rapa

Lepidium didymum

Impatiens glandulifera

Sisymbrium officinale

Stachys palustris

Vicia cracca

Alliaria petiolata

Chamerion angustifolium

Chenopodium rubrum

Dactylis glomerata

Epilobium parviflorum

Equisetum arvense

Medicago lupulina

Myosotis arvensis

Papaver rhoeas

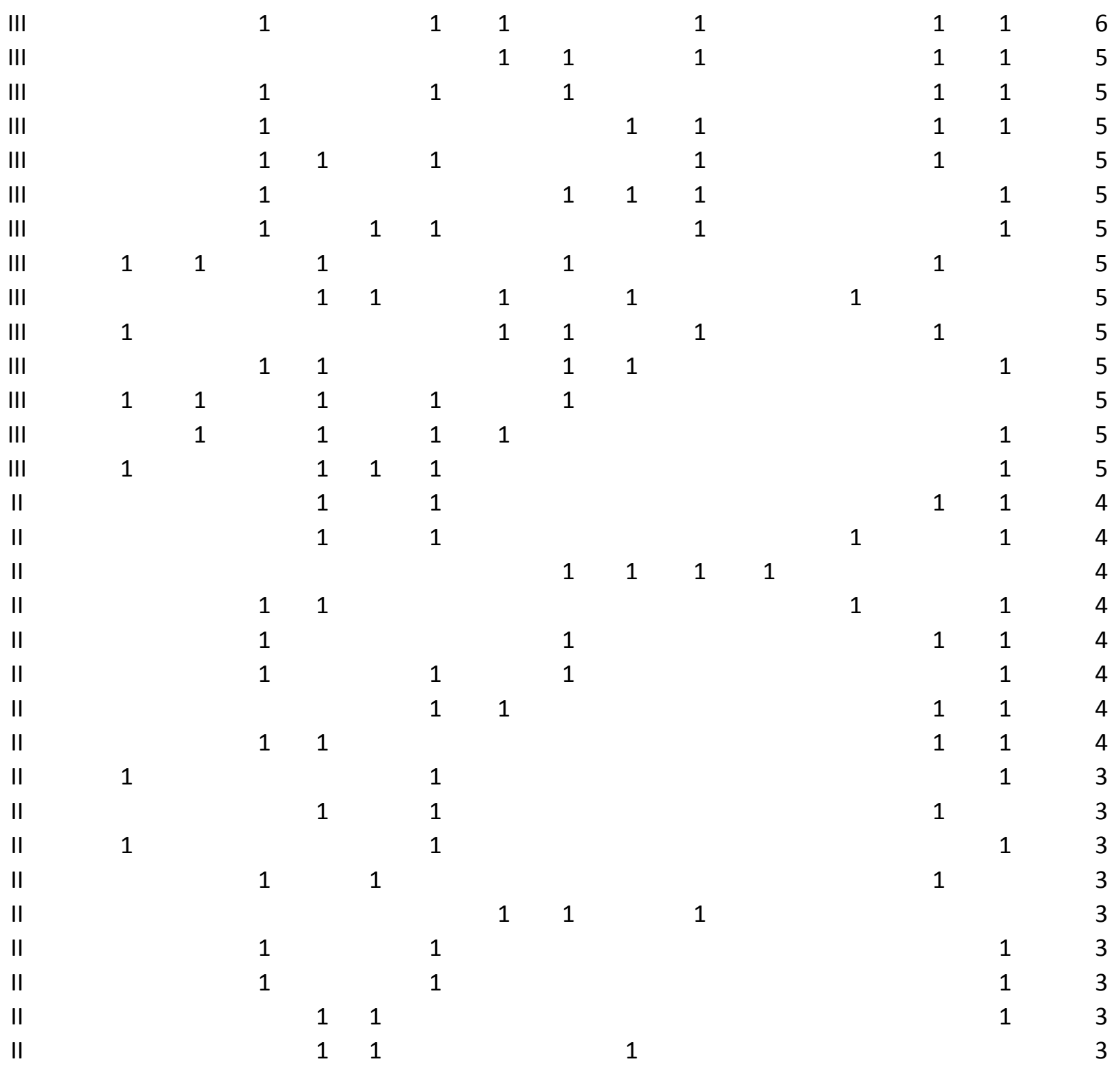


Ranunculus acris

Spergula arvensis

Trifolium repens

Tussilago farfara

Cardamine flexuosa

Galeopsis bifida

Gnaphalium uliginosum

Holcus mollis

Juncus effusus

Odontites vernus

Oenothera biennis

Phleum bertolonii

Plantago lanceolata

Rumex crispus

Salix cinerea subsp. oleifolia

Jacobaea vulgaris

Solanum nigrum

Stachys sylvatica

Trifolium dubium

Trifolium hybridum

Typha latifolia

Veronica arvensis

Vicia sepium
Arabidopsis thaliana

Lapsana communis

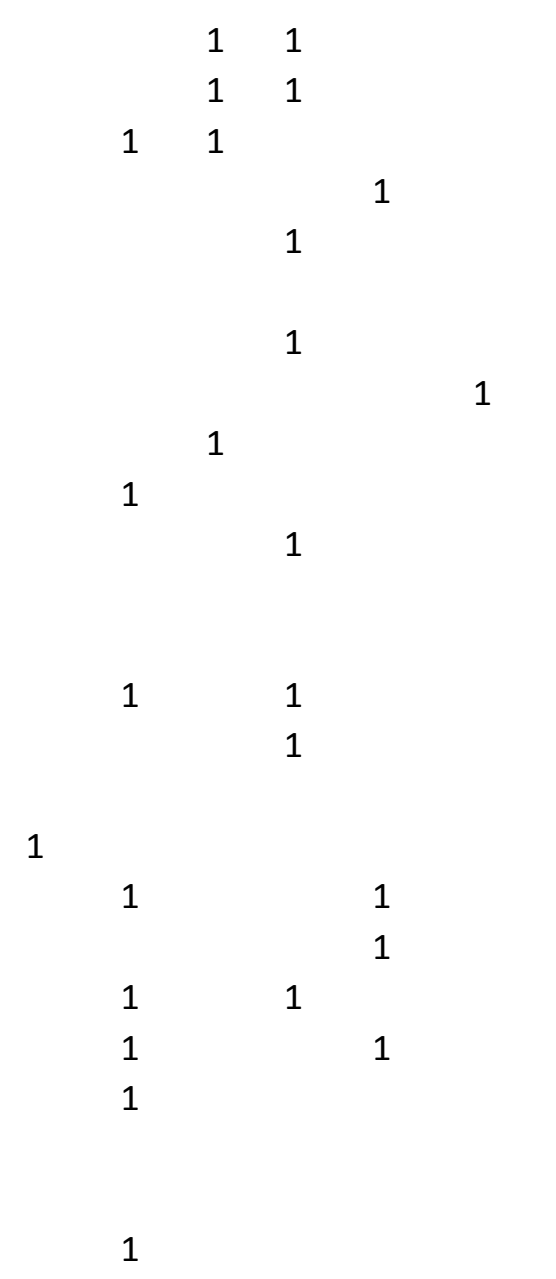

1

1

1

1

1

1

1

1

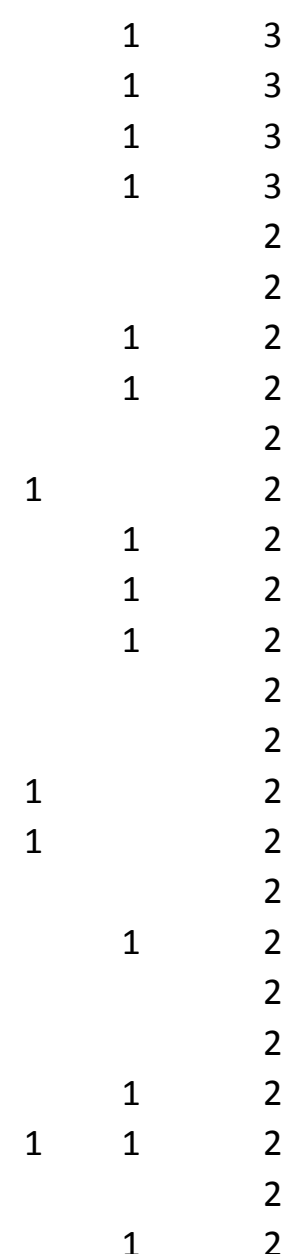

1

12

11
The following additional species were found in just 1 of the 13 samples with Galeopsis speciosa: Acer pseudoplatanus, Achillea millefolium, Agrostis gigantea, Alopecurus pratensis, Anthemis austriaca, Anthriscus sylvestris, Arctium nemorosum, Artemisia vulgaris, Brassica rapa subsp. rapa, Buddleja davidii, Calystegia sepium, Cardamine hirsuta, Chenopodium ficifolium, Crocosmia $x$ crocosmiiflora, Cymbalaria muralis, Datura stramonium, Digitalis purpurea, Epilobium montanum, Erigeron canadensis, E. 
floribunda, E. sumatrensis, Eschscholzia californica, Euphorbia helioscopia, E. peplus, Schedononorus arundinacea, Geranium dissectum, G. robertianum, Geum urbanum, Glyceria fluitans, Heracleum sphondylium, Juncus inflexus, Lepidium coronopus, Leucanthemum vulgare, Linaria vulgaris, Lolium perenne, Lotus pedunculatus, Medicago sativa subsp. sativa, Mentha spicata, Origanum vulgare, Papaver dubium subsp. dubium, Phalaris arundinacea, Poa annua, Polygonum arenastrum, Pulicaria dysenterica, Reseda luteola, Rumex acetosa, Rumex sanguineus, Salix viminalis, Scrophularia auriculata, S. nodosa, Scutellaria galericulata, Silene dioica, S. latifolia subsp. alba, S. x hampeana, Sonchus arvensis, S. oleraceus, Sorbus aucuparia, Stellaria pallida, Triticum aestivum, Typha angustifolia, Veronica serpyllifolia, Vicia sativa subsp. nigra, Vicia sativa subsp. segetalis. The low frequency of Poa annua and the absence of Sagina procumbens are remarkable.

The samples 1-14 were as follows: 1 Arboretum Meadow soil piles (September 2018), 2 Welcome Building (July 2020), 3 E end of Victoria Meadow soil piles (September 2019), 4 last active soil pile Arboretum Meadow (September 2019), $5 \mathrm{~N}$ boundary fence by Main Entrance (July 2020), 6 W boundary fence (July 2020), 7 E bank of Worsley Water (July 2020), 8 E boundary soil pile (July 2020), 9 E of The Copse (July 2020), 10 Worsley Water soil pile (July 2020), 11 Chinese Streamside Garden below Ellesmere Lake (July 2020), 12 SW soil pile Moss Basin (July 2020), 13 summit of SW soil pile (July 2020), 14 flanks of SW soil pile (July 2020) 


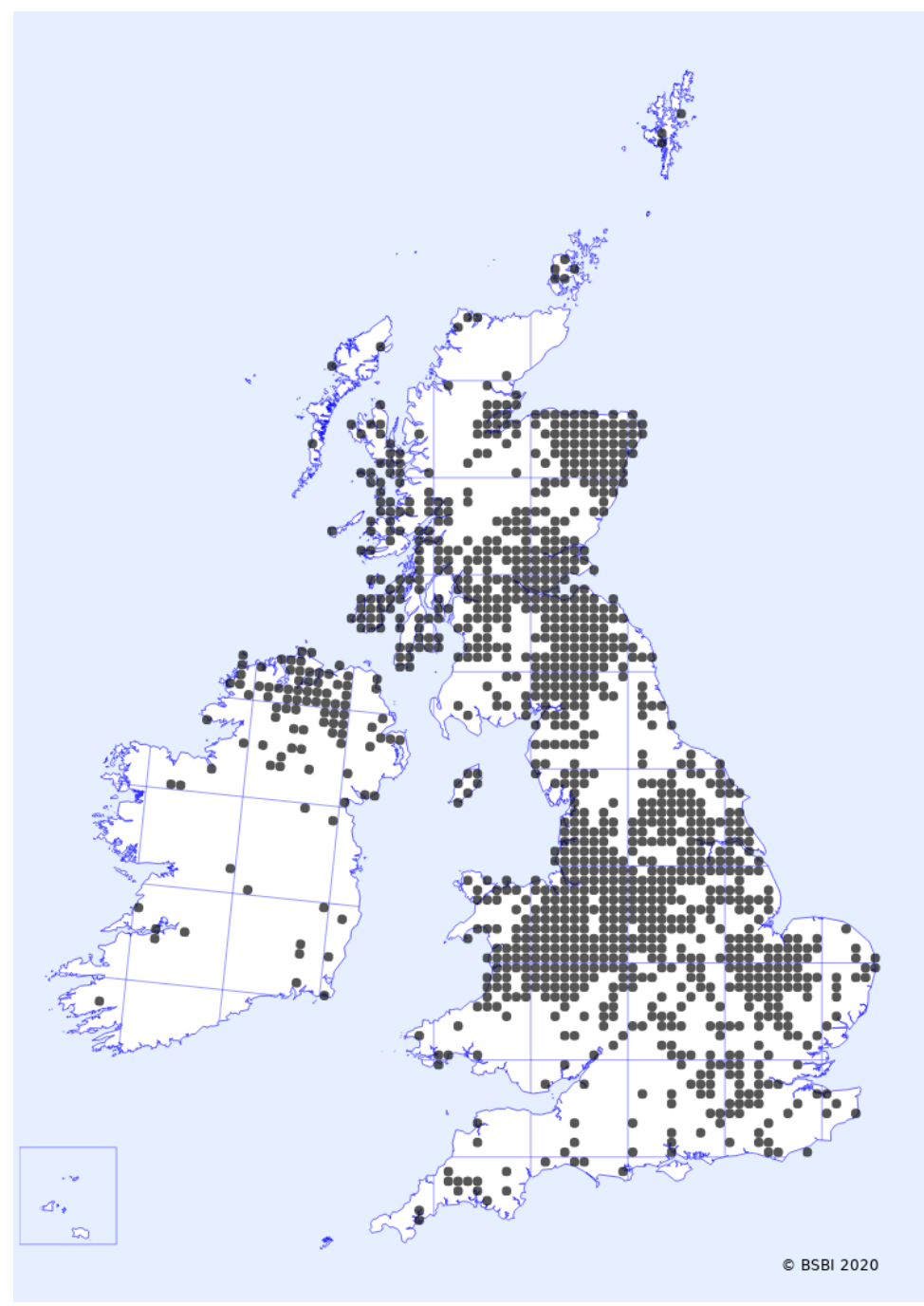

Figure 5. The spatial distribution of Galeopsis speciosa in Britain and Ireland. BSBI database 2020 (https: //database.bsbi.org/)

Soil piles using material from the northern half of the site were distinctly different in the composition of their seed banks from the black, moss-peat-derived soils in Table 2. For example, the new Service Yard is surrounded by a high mound of material (topsoil and subsoil) that was excavated for the foundations of the tractor shed and its concrete forecourt. This was intermediate between OV12 and OV13 (Rodwell, 2000) where the dominant annual plants were Brassica rapa subsp. rapa, Capsella bursa-pastoris, Cardamine flexuosa, C. hirsuta, Cerastium glomeratum, Chenopodium album, C. rubrum, Cirsium vulgare, Digitalis purpurea, Erigeron canadensis, Euphorbia helioscopia, E. peplus, Galium aparine, Geranium molle, G. robertianum, Gnaphalium uliginosum, Helminthotheca echioides, Juncus bufonius, Lapsana communis, Lepidium didymum, Matricaria chamomilla, M. discoidea, Medicago lupulina, Melilotus officinalis, Myosotis arvensis, Persicaria maculosa, Polygonum aviculare, P. rurivagum, Reseda luteola, Senecio vulgaris, Sisymbrium officinale, Solanum nigrum, Sonchus asper, S. oleraceus, Tripleurospermum inodorum and Vicia sativa subsp. segetalis. The community also included many more perennial species than did the moss-peat (presumably regenerated from vegetative fragments as well as from seed), including Agrostis 
capillaris, A. stolonifera, Alliaria petiolata, Alopecurus geniculatus, Arrhenatherum elatius, Asplenium scolopendrium, Centranthus ruber, Chamaenerion angustifolium, Cirsium arvense, Crocosmia x crocosmiiflora, Cyclamen hederifolium, Dactylis glomerata, Epilobium ciliatum, E. hirsutum, E. parviflorum, Equisetum arvense, Geranium macrorrhizum, Geum urbanum, Hedera helix, Holcus lanatus, Hypericum perforatum, Juncus bulbosus, J. conglomeratus, J. effusus, Lamiastrum galeobdolon subsp. montanum, Lolium perenne, Lotus corniculatus, Lysimachia punctata, Mentha spicata, Phuopsis stylosa, Plantago major, Polypogon viridis, Potentilla anserina, Pteridium aquilinum, Ranunculus repens, Reynoutria japonica, Rumex crispus, $R$. obtusifolius, Sagina procumbens, Scrophularia nodosa, Thymus drucei, Trifolium dubium, T. repens, Tussilago farfara, Urtica dioica and Vicia sepium.

\section{Post-construction Landscaping}

Four different wildflower mixes were employed ( 2 seed mixtures and 2 as turves): their botanical compositions are described in Table 3. The plant communities that developed where these mixtures were planted, indicate which of the sown species showed themselves in 2020, plus the local seed bank and unintentionally introduced species that recruited along with them (Table 4). The strip along the northern boundary to the east of the new entrance was sown with seeds of Emorsgate EM3 Meadow Mixture in 2018. Wildflower turf was laid in all the swales (e.g. down the western edge of the main drive, and through the main car park), around Moss Basin and as a strip along the southern wall of the walled garden in 2019. The western end of Victoria Meadow was sown with DLF Seeds Wildflower Seed Mix for Acidic Soil in late 2020 (but after the survey; it will be monitored for the first time in 2021).

Green manures, including Phacelia tanacetifolia and Sinapis alba were sown as weed suppressors in beds that were destined to lie fallow for one or more growing seasons (e.g. The Outer Walled Garden).

Details of the planting of the Paradise Garden, Kitchen Garden, New Orchard, Chinese Streamside Garden and the Arboretum will be published elsewhere. 
Table 3. Wildflower mixtures used at RHS Bridgewater in 2019 and 2020 . Emorsgate and DFL mixtures were directly sown as seeds and are ranked by the rate of application (\% of total seed sown) for each species. Tillers Turf mixtures were laid as turves, with each individual slab measuring $1200 \mathrm{~mm} \times 600 \mathrm{~mm}$ and weighing on average $15-20 \mathrm{~kg}$. For these, only the total seed rates for herbs and grasses are given. The turves were grown on moisture retentive, degradable, recycled fibre matting which acts as a barrier to suppress any indigenous and problematic broad leaved weeds and grasses

Emorsgate EM3 Meadow

Mixture

Galium verum

Daucus carota

Malva moschata

Poterium sanguisorba

Silene dioica

Centaurea debeauxii

Leucanthemum vulgare

Rumex acetosa

Centaurea scabiosa

Galium album

Plantago media

Primula veris

Betonica officinalis

Leontodon hispidus

Ranunculus acris

Rhinanthus minor

Achillea millefolium

Silene flos-cuculi

Agrimonia eupatoria

Knautia arvensis

Origanum vulgare

Prunella vulgaris

Ranunculus bulbosus rate (\%) DLF Seeds: Wildflower Seed Mix for Acidic Soil

Galium verum

Ranunculus acris

Centaurea debeauxii

Agrimonia procera

Vicia cracca

Rhinanthus minor

Leucanthemum vulgare

Silene flos-cuculi

Rumex acetosa

Achillea millefolium

Lotus pedunculatus

Achillea ptarmica

Hypochaeris radicata

Erodium cicutarium

Digitalis purpurea

Galium saxatile

Rumex acetosella

Betonica officinalis

Lotus corniculatus

Succisa pratensis rate (\%) Tillers Turf Meadow

2.2

2.2

1.8

1.8

1.4

1.4

1.2

1.2

1.2

1.2

1

0.8

0.4

0.4

0.4

0.4

0.4

0.2

0.2

0.2

0.3

0.3

0.2
Achillea millefolium

Anagallis arvensis

Anthemis arvensis

Anthyllis vulneraria

Betonica officinalis

Centaurea cyanus

Centaurea debeauxii

Daucus carota

Echium vulgare

Galium verum

Geranium pratense

Hypericum perforatum

Hypochaeris radicata

Knautia arvensis

Leucanthemum vulgare

Medicago lupulina

Papaver rhoeas

Poterium sanguisorba

Primula veris

Prunella vulgaris

Ranunculus acris

Reseda luteola
Malva moschata rate Tillers Turf Aqua

(\%)

Achillea millefolium

Betonica officinalis

Centaurea debeauxi

Daucus carota

Filipendula ulmaria

Galium verum

Leucanthemum vulgare

Linaria vulgaris

Lotus corniculatus

Lotus pedunculatus

Silene flos-cuculi

Lythrum salicaria

Malva moschata

Plantago lanceolata

Poterium sanguisorba

Prunella vulgaris

Ranunculus acris

Ranunculus repens

Rumex acetosa

Silene latifolia subsp. alba

Succisa pratensis

Trifolium pratense 
Silene latifolia subsp. alba

Geranium pratense

Taraxacum officinale agg.

Vicia sativa subsp. segetalis

total herbs

\section{Grasses}

Cynosurus cristatus

\section{Festuca rubra}

Poa pratensis

Agrostis capillaris

Phleum bertolonii

total grasses

80
0.1

0.1

20

Festuca rubra subsp. commutata

Cynosurus cristatus

Festuca ovina

Agrostis capillaris

Deschampsia flexuosa

Anthoxanthum odoratum
Rhinanthus minor

Silene dioica

Silene vulgaris

Trifolium pratense

Vicia cracca

Viola tricolor

Cynosurus cristatus

Festuca ovina

Festuca rubra

Briza media
80

Agrostis stolonifera

Alopecurus pratensis

Anthoxanthum odoratum

Cynosurus cristatus

Festuca rubra

Poa pratensis 
Table 4. The flora in July 2020 of areas sown to wildflower mix (Leigh Road in 2019) or laid with wildflower turf (Western and Car Park Swales in 2020) comprises a mix of sown and resident seed-bank species. The species sown or laid in turf are listed in Table 3

$\begin{array}{lcll}\text { Leigh Road S side (Emorsgate EM3) } & \text { dafor } & \text { Western boundary (Tillers Aqua) } \\ \text { Agrostis capillaris } & \text { f } & \text { Achillea millefolium } \\ \text { Arrhenatherum elatius } & \text { f } & \text { Agrostis stolonifera } \\ \text { Centaurea debeauxii } & \text { f } & \text { Centaurea debeauxii } \\ \text { Cynosurus cristatus } & \text { f } & \text { Cynosurus cristatus } \\ \text { Daucus carota } & \text { f } & \text { Galium album } \\ \text { Galium album } & \text { f } & \text { Leucanthemum vulgare } \\ \text { Galium verum } & \text { f } & \text { Lotus corniculatus var. sativus } \\ \text { Leucanthemum vulgare } & \text { f } & \text { Silene flos-cuculi } \\ \text { Lolium perenne } & \text { f } & \text { Lythrum salicaria } \\ \text { Lotus corniculatus var. sativus } & \text { f } & \text { Persicaria maculosa } \\ \text { Plantago major } & \text { f } & \text { Rumex obtusifolius } \\ \text { Polygonum aviculare } & \text { f } & \text { Silene dioica } \\ \text { Prunella vulgaris } & \text { f } & \text { Silene latifolia subsp. alba } \\ \text { Ranunculus acris } & \text { f } & \text { Stellaria media } \\ \text { Ranunculus repens } & \text { f } & \text { Atriplex patula } \\ \text { Rumex obtusifolius } & \text { f } & \text { Atriplex prostrata } \\ \text { Stellaria media } & \text { f } & \text { Capsella bursa-pastoris } \\ \text { Trifolium repens } & \text { f } & \text { Cerastium glomeratum } \\ \text { Alliaria petiolata } & \text { o } & \text { Chenopodium album } \\ \text { Arctium nemorosum } & \text { o } & \text { Cirsium vulgare } \\ \text { Artemisia vulgaris } & \text { o } & \text { Lepidium didymus } \\ \text { Atriplex patula } & \text { o } & \text { Fallopia convolvulus } \\ \text { Calystegia sepium } & \text { o } & \text { Fumaria officinalis subsp. officinalis } \\ \text { Chenopodium album } & \text { o } & \text { Galeopsis speciosa } \\ & \text { o } & \text { Lamium purpureum } \\ \text { antanum } & & \end{array}$

$\begin{array}{clc}\text { dafor } & \text { Car Park (Tillers Meadow) } & \text { dafor } \\ \mathrm{f} & \text { Achillea millefolium } & \mathrm{f} \\ \mathrm{f} & \text { Centaurea debeauxii } & \mathrm{f} \\ \mathrm{f} & \text { Daucus carota } & \mathrm{f} \\ \mathrm{f} & \text { Holcus lanatus } & \mathrm{f} \\ \mathrm{f} & \text { Leucanthemum vulgare } & \mathrm{f} \\ \mathrm{f} & \text { Linaria vulgaris } & \mathrm{f} \\ \mathrm{f} & \text { Lotus corniculatus var. sativus } & \mathrm{f} \\ \mathrm{f} & \text { Silene flos-cuculi } & \mathrm{f} \\ \mathrm{f} & \text { Lythrum salicaria } & \mathrm{f} \\ \mathrm{f} & \text { Persicaria maculosa } & \mathrm{f} \\ \mathrm{f} & \text { Prunella vulgaris } & \mathrm{f} \\ \mathrm{f} & \text { Ranunculus acris } & \mathrm{f} \\ \mathrm{f} & \text { Ranunculus repens } & \mathrm{f} \\ \mathrm{f} & \text { Ranunculus sceleratus } & \mathrm{f} \\ \mathrm{o} & \text { Rumex obtusifolius } & \mathrm{f} \\ \mathrm{o} & \text { Silene dioica } & \mathrm{f} \\ \mathrm{o} & \text { Silene latifolia subsp. alba } & \mathrm{f} \\ \mathrm{o} & \text { Anthoxanthum odoratum } & \mathrm{o} \\ \mathrm{o} & \text { Capsella bursa-pastoris } & \mathrm{o} \\ \mathrm{o} & \text { Cerastium fontanum } & \mathrm{o} \\ \mathrm{o} & \text { Cerastium glomeratum } & \mathrm{o} \\ \mathrm{o} & \text { Chamerion angustifolium } & \mathrm{o} \\ \mathrm{o} & \text { Chenopodium album } & \mathrm{o} \\ \mathrm{o} & \text { Cirsium arvense } & \mathrm{o} \\ \mathrm{o} & \text { Cirsium vulgare } & \mathrm{o}\end{array}$


Lepidium didymus

Epilobium hirsutum

Galium aparine

Phleum bertolonii

Phleum pratense

Helminthotheca echioides

Silene dioica

Silene latifolia subsp. alba

Sonchus arvensis

Stachys sylvatica

Urtica dioica

Ervum tetraspermum

Achillea ptarmica

Deschampsia cespitosa

Heracleum mantegazzianum

Primula vulgaris

Rumex longifolius

Senecio jacobaea

Thymus drucei

Trifolium pratense
Linaria vulgaris

Lolium multiflorum

Lolium perenne

Matricaria discoidea

Matricaria recutita

Polygonum aviculare

Prunella vulgaris

Ranunculus sceleratus

Rorippa palustris

Salix caprea subsp. caprea

Senecio vulgaris

Sisymbrium officinale

Trifolium pratense

Barbarea vulgaris

Deschampsia cespitosa

Thymus drucei

Tripleurospermum inodorum

Ervilia hirsuta

Vicia sativa subsp. segetalis

Viola arvensis
- Lepidium didymus

- Cynosurus cristatus o

- Elytrigia repens

- Epilobium hirsutum

- Filipendula ulmaria

- Holcus mollis 0

- Juncus bufonius

- Lapsana communis

- Medicago lupulina

- Papaver rhoeas o

- Persicaria lapathifolia

- Poa trivialis 0

- Rorippa palustris

$r \quad$ Sisymbrium officinale $\quad 0$

$r \quad$ Trifolium pratense

$r \quad$ Trifolium repens 0

$r \quad$ Vicia cracca o

r Atriplex patula r

$r \quad$ Atriplex prostrata r

$r \quad$ Epilobium ciliatum $r$

Epilobium montanum $r$

Epilobium palustre $r$

Galeopsis tetrahit $r$

Matricaria discoidea $r$

Salix viminalis

Stachys sylvatica

Thymus drucei

Tripleurospermum inodorum

Tussilago farfara

Viola arvensis 


\section{Discussion}

Rather little has survived of the Victorian planting of Worsley New Hall, and the flora is depauperate in species like Cedrus spp., Pseudotsuga menziesii, Abies spp., and Sequoiadendron giganteum that we might expect to find on a typical estate of this date and splendour. Where there are horticultural survivors, they are clearly of much more recent origin (e.g. Metasequoia glyptostroboides). One of the few ornamental conifers that survived at the time of purchase in 2017 was an individual of Pinus contorta subsp. latifolia that grew by the wall of Garden Cottage: it was knocked down unintentionally during pipe-laying in 2020.

As to the legacy of invasive alien plants, Bothy Wood and the adjacent Service Yard Swamp had a substantial population of Reynoutria japonica which was herbicide injected in 2019. The other problem plant was Impatiens glandulifera which was frequent and locally abundant throughout Leigh Road Woods and East Wood, on the motorway embankment, and in the scrub along the southern boundary beneath the Bridgewater Canal. The gigantic Reynoutria sachalinensis grew just outside the eastern boundary fence on the embankment of the M60 slip road.

The construction work associated with building the new RHS garden involved the movement and temporary storage of vast quantities of topsoil and this provided an opportunity to study the seed banks beneath contrasting habitats within the Warley New Hall estate. The black, peaty soils from The Moss in the south-west corner of the site proved to have a highly distinctive seed bank with Galeopsis speciosa as a major component. This is described here as a new Open Vegetation community (not in Rodwell, 2000; see Table 2). It will be interesting to see from the results of future work, over what part of the geographic range of G. speciosa (Fig. 5) the community occurs. A notable feature of this seed bank was the co-occurrence of closely related taxa: Persicaria lapathifolia along with P. maculosa and Galeopsis bifida with $G$. tetrahit. Persicaria amphibia was reported by as a pernicious weed on some of the arable soils on Carrington Moss (Price Evans, 1923), and was locally frequent on the soil piles in the south-western corner of RHS Bridgewater.

This fertile soil was used to fill many of the beds in the Paradise Garden and all the beds in the Kitchen Garden. It was also used in landscaping the ground at the newly-constructed Welcome Building and around the adjacent new lake (Worsley Water). These works will have spread the seed of Galeopsis speciosa over most of the non-wooded parts of the estate.

In assessing the flora of soil piles, there is inevitably a degree of uncertainty about the origin of the seed of the species that appear (e.g. did they come from the seed bank or by contemporary inward dispersal). Some of the more obvious nonseed-bank species were the alien fleabanes (the recently arrived Erigeron sumatrensis and E. floribunda and the longer-established E. canadensis). These typically peaked in abundance in the first year after topsoil dumping, germinating in an essentially competition-free substrate, but declined dramatically in abundance in the $2^{\text {nd }}$ and $3^{\text {rd }}$ years as competition from perennial grasses increased. Their likely origin was the embankment of the M60 motorway slip-road. Other species recorded from the soil piles had clearly come from spilled seed used in the wildflower mixtures (e.g. Anthemis austriaca, Eschscholzia californica, Leucanthemum vulgare, Linaria 
vulgaris, Lotus pedunculatus, Medicago sativa subsp. sativa, Mentha spicata, Origanum vulgare, Papaver dubium subsp. dubium).

The use of wildflower mixtures in semi-natural habitats outside a horticultural setting has become controversial in recent decades (May, 1994), especially where it has been shown that species being sold as native wildflowers were actually alien species (e.g. Cota austriaca instead of Anthemis arvensis), alien subspecies (e.g. Poterium sanguisorba subsp. balearicum) or alien varieties (e.g. Lotus corniculatus var. sativus) purchased cheaply overseas from agricultural suppliers and sold at considerable profit in Britain. The extensive use of well-documented seed mixtures in landscaping at RHS Bridgewater affords an opportunity to follow the establishment and subsequent survival of a set of British native species that were not previously part of the flora of the estate. It will be particularly interesting to follow the fate of any of these introduced species that become naturalised and increase in abundance, indicating that previously their recruitment had been seed-limited (Turnbull et al., 2000 ). None of the sown species has any reputation for invasiveness (see Stace \& Crawley, 2015).

The plan is to record and publish details of the horticultural planting as the garden develops over the years, so that we can tease apart the origins of the botanical changes that are bound to occur: planned introductions, legacy effects and unintended arrivals. This will form a unique archive on the interaction between horticulture and ecology.

\section{References}

Curtis, W. 1777-98. Flora Londinensis: or Plates and Descriptions of such plants as grow wild in the Environs of London. London: for the author and B. White.

Dickinson, J. 1851. The Flora of Liverpool. London: John Van Voorst; Liverpool: Deighton \& Lawton.

Grindon, L.H. 1859. The Manchester Flora. A descriptive list of the plants growing wild within eighteen miles of Manchester. London: Whittaker \& Co.

Karlsson, L.M., Ericsson J.A.L. \& Milberg, P. 2006. Seed dormancy and germination in the summer annual Galeopsis speciosa. Weed Research 46: 353-361.

May, R.M. 1994. Conceptual aspects of the quantification of the extent of biological diversity. Philosophical Transactions of the Royal Society of London B 345: 13-20.

Newton, A. 1971. Flora of Cheshire. Chester: Chester Community Council.

Price Evans, E. 1923. Carrington Moss, with special reference to the weeds of arable ground. Journal of Ecology 11: 64-77

Rodwell, J.S. 1991a. British Plant Communities. Vol 1. Woodlands and scrub. Cambridge: Cambridge University Press.

Rodwell, J.S. 1991b. British Plant Communities. Vol 2. Mires and heaths. Cambridge: Cambridge University Press.

Rodwell, J.S. 1992. British Plant Communities. Vol 3. Grasslands and montane communities. Cambridge: Cambridge University Press.

Rodwell, J.S. 1995. British Plant Communities. Vol 4. Aquatic communities, swamps and tall-herb fens. Cambridge: Cambridge University Press.

Rodwell, J.S. 2000. British Plant Communities. Vol 5. Maritime communities and vegetation of open habitats. Cambridge: Cambridge University Press. 
Savidge, J.P., Heywood, V.H. \& Gordon, V. 1963. Travis's Flora of South Lancashire Liverpool: Liverpool Botanical Society.

Stace, C.A. 2019. New Flora of the British Isles. $4^{\text {th }}$ ed. Middlewood Green, Suffolk: C\&M Floristics.

Stace, C.A. \& Crawley, M.J. 2015. Alien Plants. Collins New Naturalist \#129. London: Harper-Collins.

Tansley, A. G. (ed.) 1911. Types of British Vegetation. Cambridge: Cambridge University Press.

Turnbull, L. A., Crawley, M. J. \& Rees, M. 2000. Are plant populations seed-limited? A review of seed sowing experiments. Oikos 88: 225-238.

Warren, J.B.L. 1899. The Flora of Cheshire by Lord de Tabley. London: Longmans, Green and Co.

Wheldon, J.A. \& Wilson, A. 1907. The Flora of West Lancashire. Liverpool: Henry Young \& Sons.

Wood, J. B. 1840. Flora Mancuniensis. Halifax: Leyland \& Son.

Copyright retained by author(s). Published by BSBI under the terms of the Creative Commons Attribution 4.0 International Public License.

ISSN: $2632-4970$

https://doi.org/10.33928/bib.2020.02.377 


\section{Appendix A}

The time-line for the building work was as follows. Clearance of the scrub from the Walled Garden began in February 2017. Engineering work for the entrance drive and the road-widening associated with construction of the new junction onto Leigh Road was in full swing in May 2018. Removing the topsoil from North Moss, South Moss and the site of the Welcome Building, and storing it in the Arboretum and at the eastern end of Victoria Meadow, began in spring 2018. Work to restore the brickwork of the Walled Garden began in June 2018, restoring over $1.4 \mathrm{~km}$ of walls: 100,000 original bricks were removed, 80,000 individually cleaned by hand and reused. In September 2018 heavy plant machinery was back in the Walled Garden to deal with the legacy of the Victorian practice of using arsenic as a weed killer; the contaminated soil had to be dug out and removed. Big machinery was also brought in to desilt the historic Ellesmere Lake in October 2018, after the long hot summer had allowed it to dry out: $3000 \mathrm{~m}^{3}$ of silt was removed in preparation for restoring the walls, refilling and replanting the lake. Pile-driving through the peat for the foundations of the Welcome Building began on 14 Feb 2019, at which time excavating the storm-water detention lake at Moss Basin and creating the southwestern soil mounds were under way. February 2019 also saw the excavation of the new Service Yard and creation of the surrounding bund. The hard surface of North Moss car park was laid between February and May 2019. Excavating the new lake at Worsley Water began in June 2019. Between May and September 2019, 8,000 $\mathrm{m}^{3}$ of topsoil was carted back from the storage piles in Arboretum and Victoria Meadow to fill the newly constructed beds in the Paradise Garden and Kitchen Garden. New paths though the woodland, to follow the course of the proposed Chinese Streamside Garden were begun in September 2019. Topping-out of the Welcome Centre was in November 2019. Creation of the rocky stream-bed for the Chinese Streamside Garden began in January 2020. Landscape planting involving sowing and turfing with wildflower mixtures began in February 2020. The Retail area was completed in October 2020. The ground around the Welcome Building and the new Worsley Water was scheduled for sowing with wildflower seed in late 2020 (this was not surveyed as part of the present study). 